\title{
Petrography and source rock potential of Chia Gara Formation (Late Jurassic-Early Cretaceous) in Northern Iraq and Kurdistan Region
}

\author{
Ayad N. F. Edilbi ${ }^{1}$ (D) Govand H. Sherwani ${ }^{2}$
}

Received: 5 August 2018 / Accepted: 8 April 2019 / Published online: 13 April 2019

(c) The Author(s) 2019

\begin{abstract}
The petrographic characteristics and petroleum potential of Chia Gara Formation (Late Jurassic-Early Cretaceous; TithonianBerriasian) in Northern Iraq are studied. In order to find out the disparity of Chia Gara Formation in different tectonic zones, two outcrops (Banik and Barsarin sections) and well-Aj-12 were used for this study. In general, the Chia Gara Formation is lithologically composed of black shale, thin-bedded brown argillaceous limestone, thin to medium yellowish limestone. Petrographic study shows that the matrix is mainly composed of micrite, and various diagenetic processes had influenced limestones of Chia Gara Formation, such as neomorphism, dissolution, calcification, cementation and compaction. Fracture, vuggy and moldic are common types of porosity that were observed in this study. However, porosity was later destroyed by some diagenetic processes. The destruction of porosity resulted in considerably low permeability. In addition to petrography, the source rock potential of Chia Gara Formation was also studied. The average values for Total Organic Carbon in percentage (TOC\%) of the formation were 1.70, 3.40 and 0.89 for Barsarin, Banik and Aj-12 sections, showing good, very good, and fair organic carbon content, respectively. The pyrolysis executed for studied samples revealed that kerogen type of Chia Gara Formation in Banik section and well Aj-12 belongs to type-II and type-III kerogens, whereas Barsarin section belongs to type-III and type-IV kerogens. The plot of TOC\% versus generation potential $(\mathrm{S} 1+\mathrm{S} 2)$ indicated poor to very good potential of hydrocarbon generation for studied samples. The values of the $T_{\max }$ (the temperature that results in the maximum release of hydrocarbons (S2) during pyrolysis program) suggested that the organic matter in Banik and Barsarin sections is in mature stage, whereas it is thermally immature (or late immature) in well Aj-12. Vitrinite reflectance (R\%) also indicated Oil Window to Early Gas Window in Barsarin, Oil Window in Banik, and Early Oil Window in Aj-12. This study revealed that the studied sections from different tectonic zones show slightly different stages of thermal maturity. The high thermal maturity in Barsarin area can be resulted in different type of kerogen compared to the other sections.
\end{abstract}

Keywords Chia Gara $\cdot$ Source rock $\cdot$ Diagenesis $\cdot$ Reservoir characteristics $\cdot$ Porosity $\cdot$ Kurdistan region

\section{Introduction}

The presence of suitable petroleum source rocks is essential for creation of effective petroleum system which constrains the petroleum potential of under-explored basins (Curiale 1994). Carbonate source rocks may form in variety of depositional environments, including lake, evaporitic shallowmarine platforms, and deeper marine basin (Demaison and

Ayad N. F. Edilbi

ayad.faqi@soran.edu.iq

1 Department of Petroleum Geosciences, Soran University, Soran, Kurdistan Region, Iraq

2 Department of Civil Engineering, Cihan University, Erbil, Kurdistan Region, Iraq
Moore 1980). Source rock should be enriched with organic matter of specific characteristics which are found in finegrained carbonate rocks believed to result from depositional factors and diagenesis of predominantly sapropelic organic matter under reducing, non-catalytic conditions (Hunt 1996).

In Iraq, most reservoir rocks belong to Cretaceous and Tertiary Periods, while their source rocks are from Jurassic and Lower Cretaceous (Aqrawi et al. 2010; English et al. 2015; Aqrawi and Badics 2015). Northern and Northeastern Iraq were suitable locations of marine deposition since Mesozoic Era. The global rise in temperature and deposition of carbonate rock, marl, and shale, created good source rocks in Upper Jurassic-Cretaceous. Accordingly, the stratigraphy and source rock evaluation of Jurassic formations require detailed study. The Chia Gara Formation

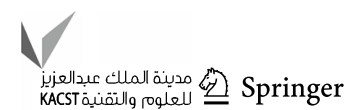


is one of the most important potential source rocks in the Late Jurassic-Early Cretaceous especially in Kurdistan Region. The Chia Gara Formation (Middle Tithonian-Berriasian) was first defined by Wetzel (1950) at Chia Gara anticline, located to the south of Amadia town in the High Folded Zone. The thickness of this formation at its type locality is $232 \mathrm{~m}$ and composed of thin-bedded limestones and shales, containing rich ammonite faunas, and grading upwards to yellowish marly limestones and shales (Bellen et al. 1959).

Almost all previous studies on Chia Gara Formation show that the formation can be considered as potential source rock (Odisho and Othman 1992; Al-Ameri and Al-Obaidi 2004; Mohyaldin and Al-Bayati 2008; Mohyaldin 2008; Al-Badry 2012; Edilbi and Sherwani 2018). Oil-source correlation and biomarker characteristics of oils and oil/bitumen seeps reveal that there is a genetic relationship between these oils and extracted organic matter from the Chia Gara source rock (Mohialdeen et al. 2013; Al-Jaafary and Hadi 2015; Edilbi 2016). Most of these studies were carried out at a local or one or two tectonic zones. Thus, the main objectives of this study are to address the petrographic characteristics of the carbonate units, and to evaluate the petroleum potential of the Chia Gara Formation from different tectonic zones.

\section{Study area and geological background}

Three locations were chosen for the current study of the Chia Gara Formation (Fig. 1). These include Barsarin village

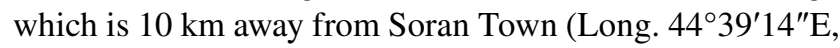
Lat. $36^{\circ} 37^{\prime} 46^{\prime \prime} \mathrm{N}$ ), Banik village which is located at about $25 \mathrm{~km}$ northeast of Zakho City (Long. 42 $58^{\prime} 2.6^{\prime \prime} \mathrm{E}$, Lat. $\left.37^{\circ} 13^{\prime} 33.4^{\prime \prime} \mathrm{N}\right)$, and Well Ajil-12 (Aj-12) within the Ajil oil field. This well lies $2650 \mathrm{~m}$ southeast of the famous produc-

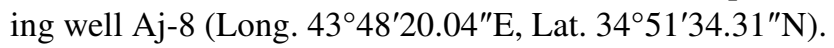

As a result of plate tectonic activity in Northern and Northeastern territory of Iraq, Jurassic and Cretaceous rocks became commonly exposed at some eroded cores and limbs of anticlines in High Folded, Imbricated, and Thrust Zones. The studied locations of the Chia Gara Formation (Barsarin, Banik, and $\mathrm{Aj}-12$ ) are situated in three different tectonic zones (Fig. 1) including the Chia Gara in Barsarin area located within the Zone of Imbrication of

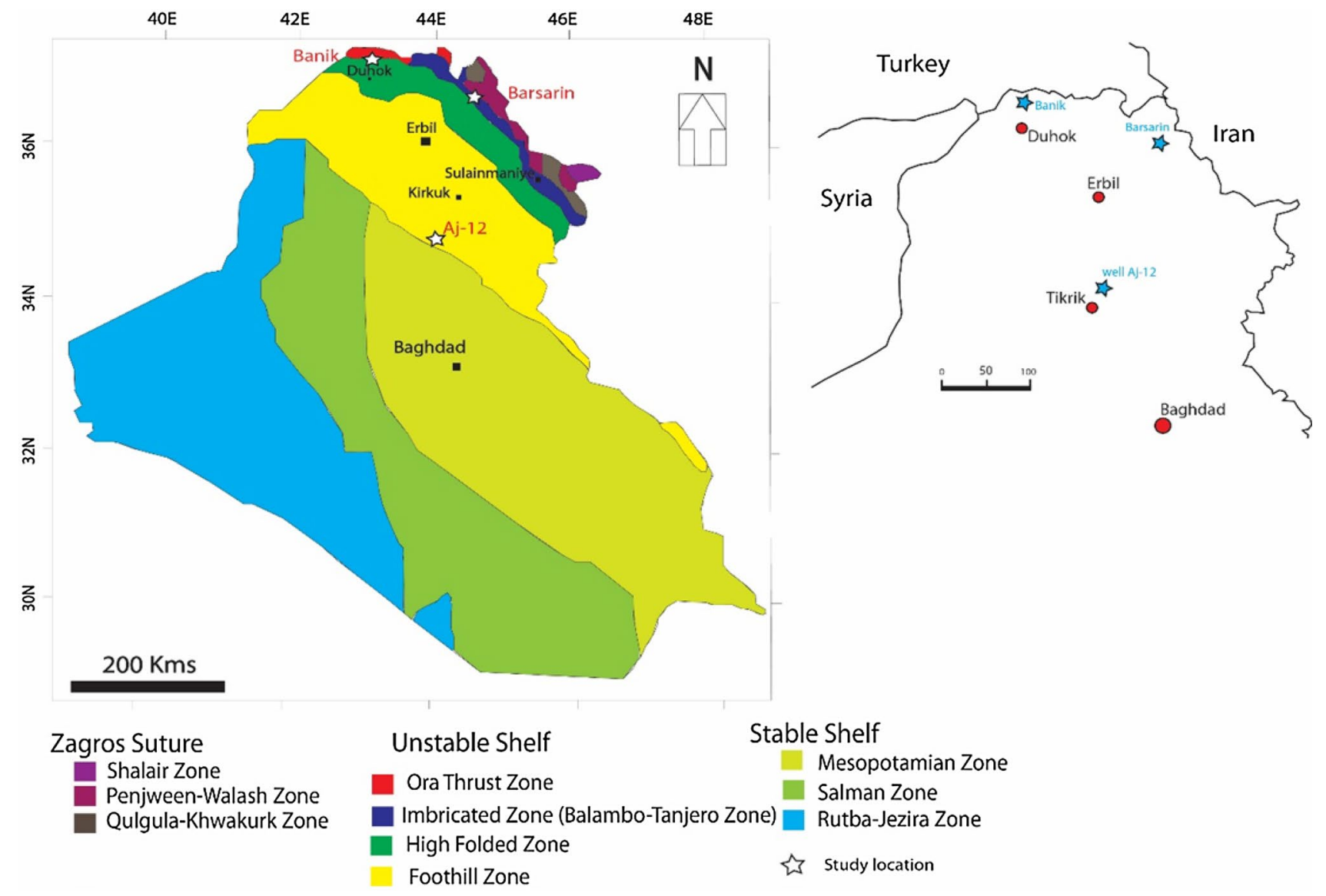

Fig. 1 Location and tectonic map of the study areas (Tectonic map is modified from Numan (2000), Jassim and Buday (2006), studied area map is modified from Google Earth (2018) 
the Foreland Basin, the Chia Gara in Banik area located within the High Folded Zone of the Foreland Basin, and well Aj-12- in Tikrit area located in the Foothill Zone.

During the Late Mesozoic and Early Cenozoic, sedimentation in the present Mesopotamian Basin and Zagros Fold Belt was controlled by local tectonics, eustatic sea-level changes and climate variations. From Jurassic through Late Cretaceous, sea-level fluctuations in conjunction with slow subsidence led to formation of large, but shallow intra-shelf basins on the passive margins of the Neo-Tethys Ocean and the Arabian Plate (Murris 1980; Al-Sharhan and Nairn 1997). The Chia Gara Formation was deposited in Late Jurassic-Early Cretaceous as global separation and expansion time within the deep outer shelf of the Arabian Plate Margins (Numan 1997). In Kurdistan territory, the formation is arbitrarily limited at the Valanginian-Berriasian stage, as evidenced by faunal content (Bellen et al. 1959). The formation is deposited in the Late Tithonian-Turonian megasequence (8) of Arabian Plate (AP8) in a large intra-shelf basin contemporaneous with a new phase of ocean floor spreading in southern Neo-Tethys (Sharland et al. 2001). The depo-axis of that intra-shelf basin had shifted toward eastern Mesopotamian Zone into the Tigris Subzone from its previous position on the Salman Zone and western Mesopotamian Zone (Jassim and Buday 2006). The eastern margin of the basin was probably formed by a carbonate ridge which bordered the continental margin along the southern Neo-Tethys.

Figure 2a shows the paleogeography of Late Tithonian-Early Berriasian, interval of the Arabian Plate. The basinal configuration of that stage displays similar distribution of facies between Late Jurassic and Early Cretaceous. The disparity of thickness between the sections of Kurdis$\tan$ Region and the well sections near Tigris area is rather small. In Kurdistan area, the sediments comprise about 91.44-182.88 m thick of radiolarian shales and thin-bedded limestone with abundant ammonites, having the lower beds heavily impregnated with bitumen (Dunnington 1958) (Fig. 2b).

The fossil content of Chia Gara Formation generally indicates Middle Tithonian-Berriasian age (Bellen et al. 1959). Widely distributed over the more northerly part of the unstable shelf is the Chia Gara Formation, which interfingers with Makhul and Karimia Mudstone Formations in the Foothill Zone of Iraq. Over the stable shelf and the southwestern part of the unstable shelf in Iraq, the upper sub-cycle is represented by Sulaiy Formation (Tithonian) (Buday 1980).

The Chia Gara Formation is characterized by wide geographic extension and various thicknesses in Kurdistan Region (North and Northeast Iraq); their outcrops and subsurface sections were observed in High Folded, Imbricate Zones from Zakho to Sirwan Gorge. The isopach map of

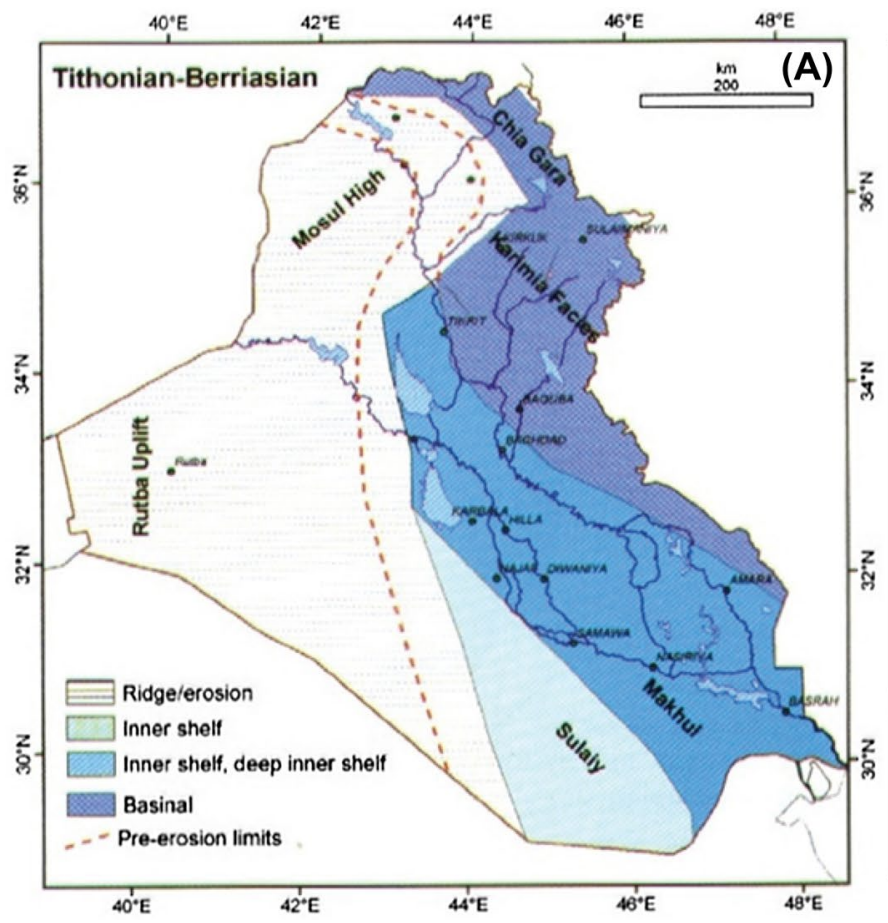

Fig. 2 a Late Tithonian-Early Berriasian Paleogeography of Iraq (Jassim and Buday 2006), b Isopach-Facies map of Upper Jurassic rocks (Dunnington 1958). As shown in the figure, thickest deposi-

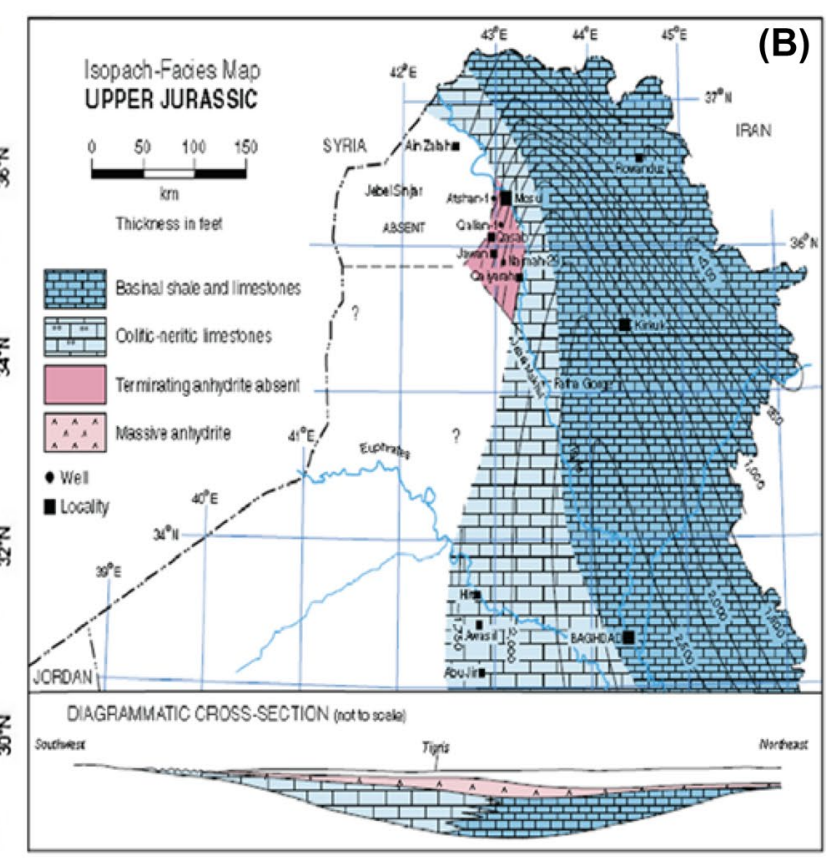

tion area in central part of Iraq would probably lie between the Tigris, North of Mosul, and Kirkuk area during Late Jurassic 
Dunnington (1958) (Fig. 2a) shows that thickest deposition area within the central part of Iraq would probably lie between the Tigris, North of Mosul, and Kirkuk area.

\section{Materials and methods}

\section{Field work}

The initial step was choosing some appropriate locations for this study and taking samples from the outcrops with description and drawing of columnar sections. Table 1 shows the details of sampling method. The boundaries between formations were marked for each outcrop and all samples were taken along a line perpendicular to the bedding plane (strike line).

\section{Laboratory work}

\section{Thin section analysis}

A total of 69 thin sections were prepared in the laboratory of Geology Department in College of Science, Salahaddin University, in addition to 28 cuttings samples provided by Northern Oil Company (NOC). All thin sections were oriented and stained with Alizarin Red Solution (ARS) technique for detecting calcite and dolomite. The petrographic study and microfacies analysis were later executed using a Leica microscope.

\section{Organic geochemistry analysis}

Several organic geochemistry tests were carried out on samples from outcrop (hand specimen) and well (cuttings), including Rock-Eval Pyrolysis and vitrinite reflectance (\%Ro) at Weatherford Laboratory, Texas, USA (Table 2).

\section{Lithostratigraphic description of studied sections}

\section{The Chia Gara formation in Barsarin section}

The lower part of Chia Gara Formation starts with shale unit followed by alternating shales with thin brown beds of argillaceous limestone. Thickness of Chia Gara Formation is around $198 \mathrm{~m}$ in Barsarin section. The lower part includes shales with argillaceous limestones and black limestones having thickness of $5-45 \mathrm{~cm}$. The middle part shows increase in argillaceous limestones with decreasing shales, while the upper part consists of limestones that interbedded with thin beds of argillaceous limestone and laminated shale. The uppermost part of this section represents alternating limestones, marly limestones with marls (Fig. 3). The ammonite fossils are well observed in this section. The lower part contains "Ball and Pillow" structure (Phacoid bed of Bellen et al. 1959) which might have formed due to syndepositional motion in a slope with little transportation. This structure is considered as an index feature of Chia Gara Formation (Fig. 8h).

\section{The Chia Gara Formation in Banik section}

The lithologic details of this section are similar to that of the Barsarin section but with less thickness. This section is lithologically homogenous, including successions of shales and thinly bedded of argillaceous limestones. Thickness of formation in this section declines to $60 \mathrm{~m}$. The first bed of Chia Gara starts with shales alternating with argillaceous limestones, notably rich in organic matter. From the lower to upper part, fissile shales decrease, whereas argillaceous limestones and limestones increase. The uppermost part is marl and marly limestone (Fig. 4). The ammonite fossils were obvious in carbonate concretion and limestone.

\section{The Chia Gara Formation in Well Aj-12 (3222- $3444 \mathrm{~m}$ )}

In this well, Chia Gara Formation consists of dark grey limestones, fine crystalline, medium hard, pyritic and shaly limestones. Fauna includes radiolarian with bituminous
Table 2 Number of samples used for Organic Geochemistry

\begin{tabular}{lll}
\hline Sections & \multicolumn{2}{l}{ Tests } \\
\cline { 2 - 3 } & Rock-Eval & Ro \% \\
\hline Barsarin & 4 & 3 \\
Banik & 4 & 3 \\
Aj-12 & 7 & 3 \\
Total & 15 & 9 \\
\hline
\end{tabular}

Table 1 Sampling method and number of samples

\begin{tabular}{llll}
\hline Section & Spacing & Method of sampling & No. of samples \\
\hline Barsarin (outcrop) & $3 \mathrm{~m}$ & Systematic (Rhythmic) & 73 \\
Banik (outcrop) & Indefinite & Random (at each change in lithology) & 40 \\
Aj-12 (Well) & $5 \mathrm{~m}$ & Systematic (for cutting samples) & 44 \\
Total & & & 157 \\
\hline
\end{tabular}

إسوبنة الملك عبدالعزيز

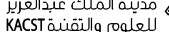




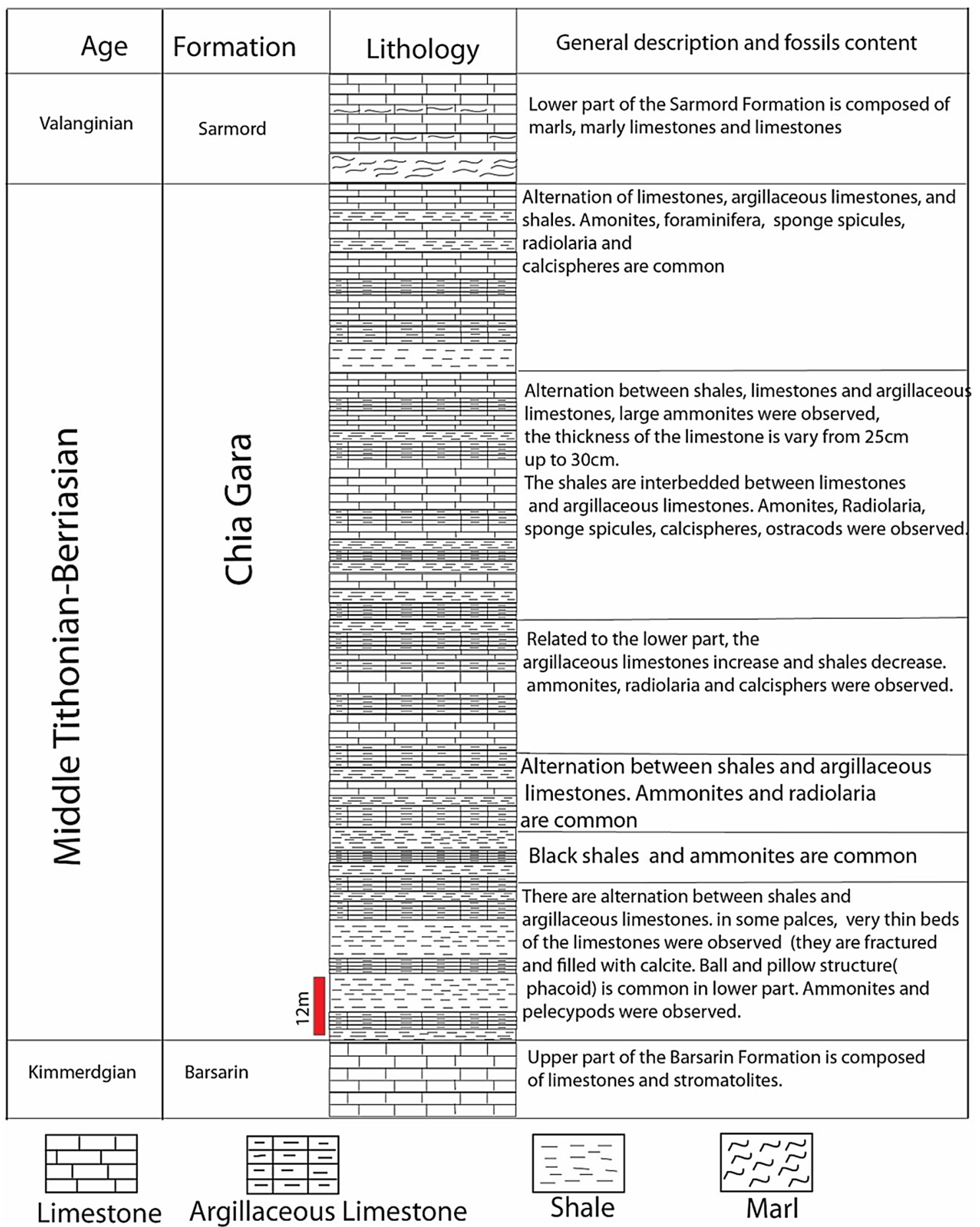

Fig. 3 Stratigraphic column of Chia Gara Formation in Barsarin Section, Erbil, Kurdistan Region

limestones, black micritic soft to medium hard and slightly fissile, shaly carbonaceous limestone. Floating Dolomite crystals were recorded within black bituminous limestone and fissile shale at the lower part. The thickness of Chia Gara Formation is reported $222 \mathrm{~m}$ (NOC 1985) (Fig. 5). 


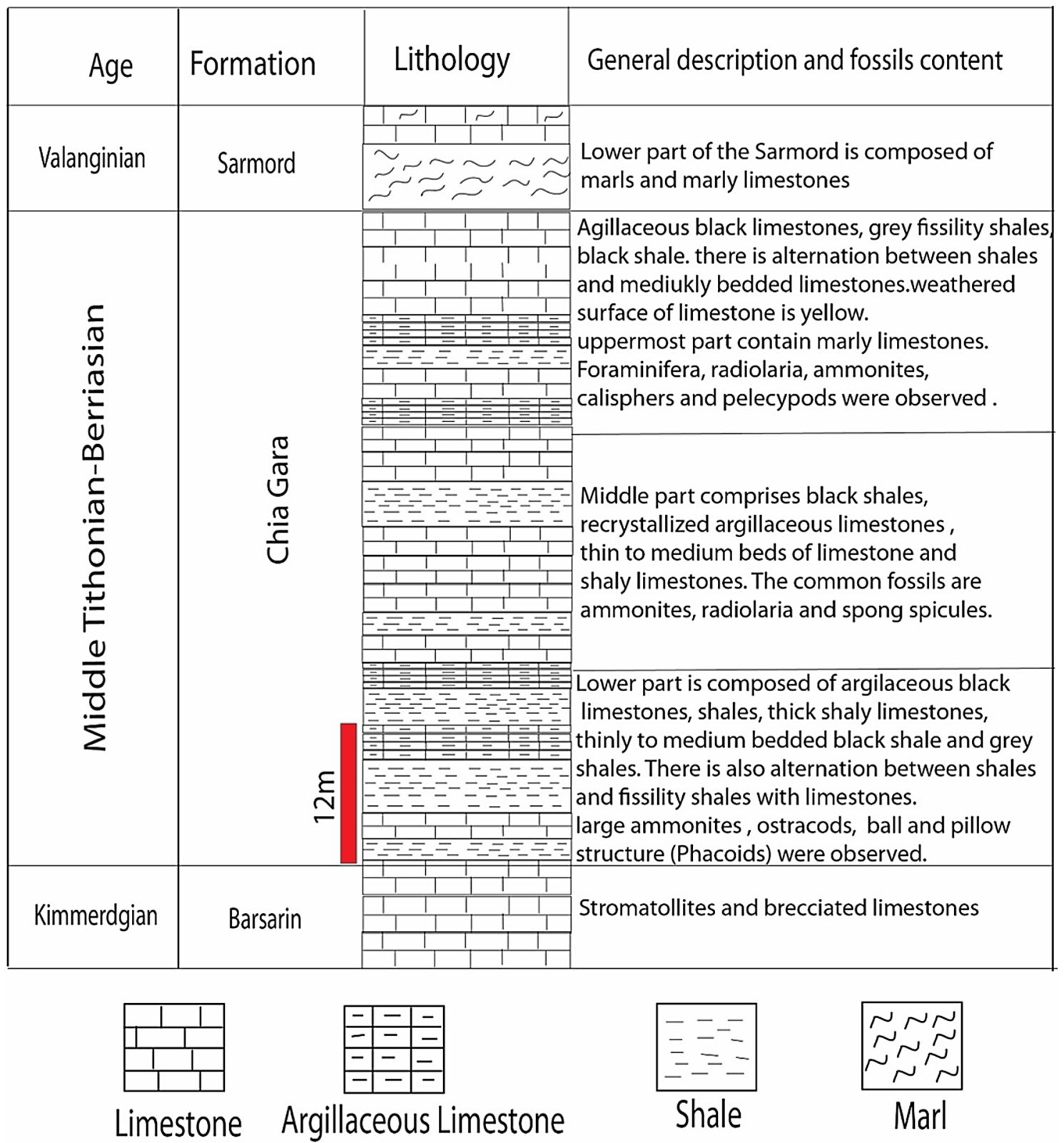

Fig. 4 Stratigraphic column of Chia Gara Formation in Banik Section, Duhok, Kurdistan Region

\section{Results and discussion}

\section{Petrography and diagenesis}

Petrography of the Chia Gara Formation implies diagenetic processes and their effects on rocks and their constituents such as grain types (Allochems) and groundmass (matrix). These processes would clearly influence the reservoir/source properties of these rocks. The groundmass of Chia Gara Formation is dominated by micrite (Figs. 6a, b, 9b) that was replaced by coarser microspar, particularly in Banik section (Fig. 7e)
Several diagenetic processes had affected the Chia Gara Formation through two main stages (Paragenesis) in Mesogenetic, and Telogenetic (Fig. 10, Table 3).

Cementation is a common process in the studied sections. Several types of cements are recognized including Granular Cement (Fig. 7b), Blocky Cement (Fig. 7d), and Drusy Cement (Fig. 7c).

The rocks of Chia Gara Formation are commonly affected by neomorphism particularly in lower and middle part of Barsarin and Banik sections (Fig. 7e). This may indicate that diagenesis was more intensive in these two sections than that in well Aj-12. 


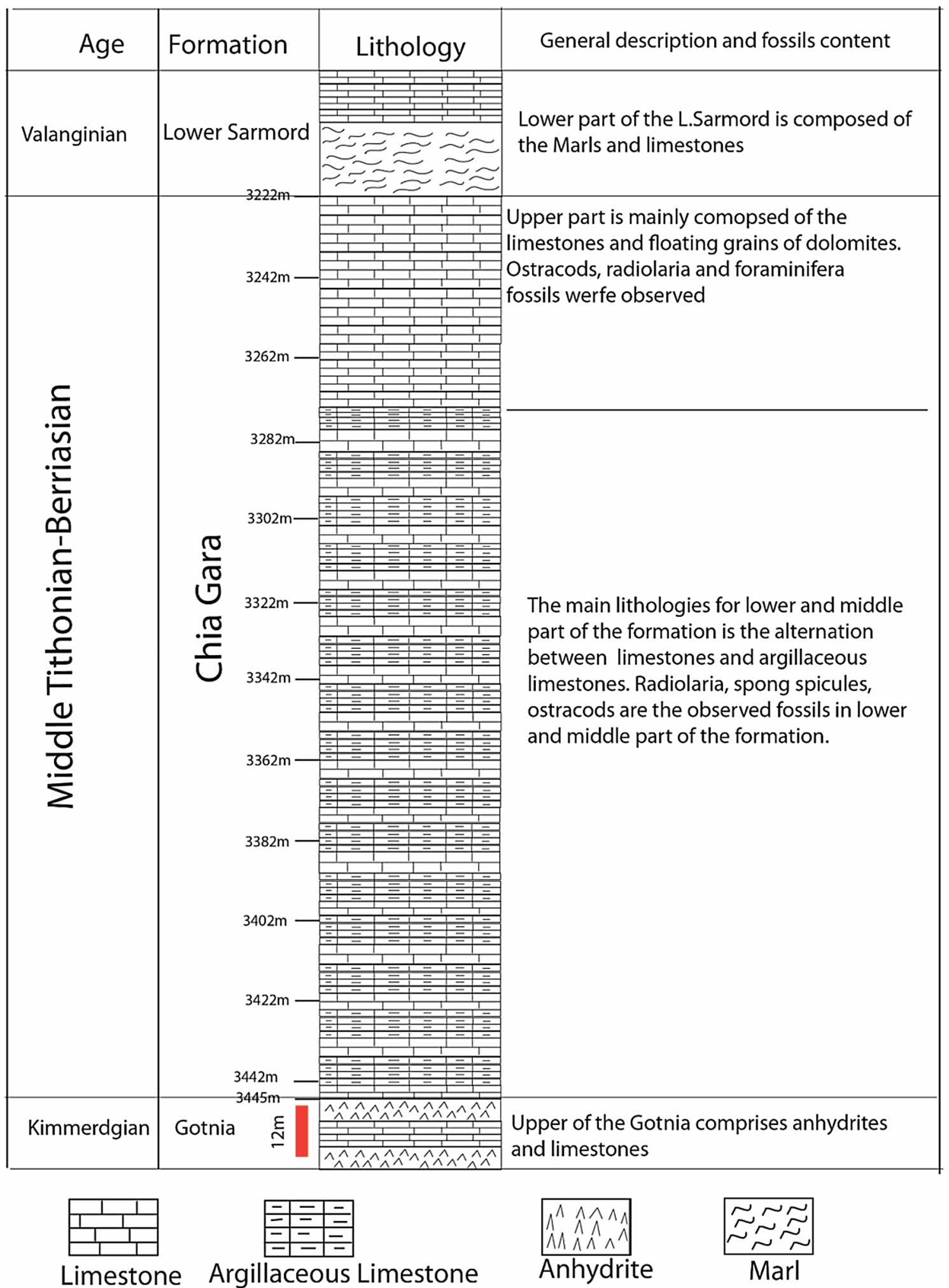

Fig. 5 Stratigraphic column of Chia Gara Formation in Well Aj-12, Salahaddin Governorate, Iraq (drawn upon description from NOC report 1985) 



Fig. 6 a Planktonic Forams (Globigerina) in micrite matrix, chamber partially bearing pyrite (arrow), Bk-38, P.P., b Articulated ostracods filled with granular cement, in micritic matrix, Bk-1, P.P. c Calcisphere filled with calcite (a) and associated with radiolaria (b), gen-

The common criteria for identifying mechanical compaction in Chia Gara Formation are fractures usually filled with sparry calcite cement derived from pressure solution and of post-compactional diagenesis (Fig. 8a), breakage of grains (Fig. 8b), and orientation of grains (Fig. 8c).

Stylolites are irregular, suture-like contacts produced by differential vertical movement under pressure accompanied by solution (Flugel 2010). In this study, only one type of stylolite (non-sutured) was observed (Fig. 8d). The Chia Gara Formation is highly fractured (macrofractures and microfractures), and this may be due to burial overpressure of (Figs. 6c, 8a, e, f). One of the prominent diagenetic processes that may have affected the limestone units of the Chia Gara is the dissolution of skeletons of siliceous radiolarian, and precipitation of calcite in their molds (Figs. 6d, $8 \mathrm{~b})$. The change in $\mathrm{pH}$ condition and rising temperature stimulate the dissolution process of siliceous radiolarian skeletons (Li and Schoonmaker 2004). Some phosphatized bioclasts were also observed in rocks of Chia Gara Formation, only in one thin section belonging to lower part of Barsarin section (Fig. 8d).

eration of fracture refers to early diagenesis, $\mathrm{Br}-45$, P.P. d radiolaria (Spumellaria), the tests are replaced by sparry calcite cement, Aj-12 (3402 m), P.P. (Note: Bk: Banik, Br: Barsarin, Aj-12: Well Ajil-12, P.P.: Plane Polarized, X.N.: Crossed Nicols)

Sign of Dolomitization in Chia Gara Formation was observed in well Aj-12 as floating crystals (Fig. 8g). The floating crystals of dolomite may refer to late burial diagenesis in this Formation. Since Chia Gara Formation was deposited in deep environment (Mohyaldin 2008), then reducing conditions, necessary for pyritization, were readily available, particularly during early burial stages when anaerobic bacteria became active (Larsen and Chilingar 1979) (Fig. 9d).

\section{Effects of diageneses on Chia Gara rocks}

Porosity is an important rock property because it is a measure of the potential storage volume for hydrocarbons (Lucia 2007). Porosity is destroyed or reduced through cementation, compaction and gained through solution, dolomitization and tectonic fractures (Choquette and Pray 1970). Using the terminologies of Lucia (2007), several types of porosity were observed in Chia Gara Formation: separate vugs which are typically fabric-selective in their origin. The Touching vugs are typically non-fabric- selective in origin (Table 4). The Chia Gara Formation generally consists of two lithologic 

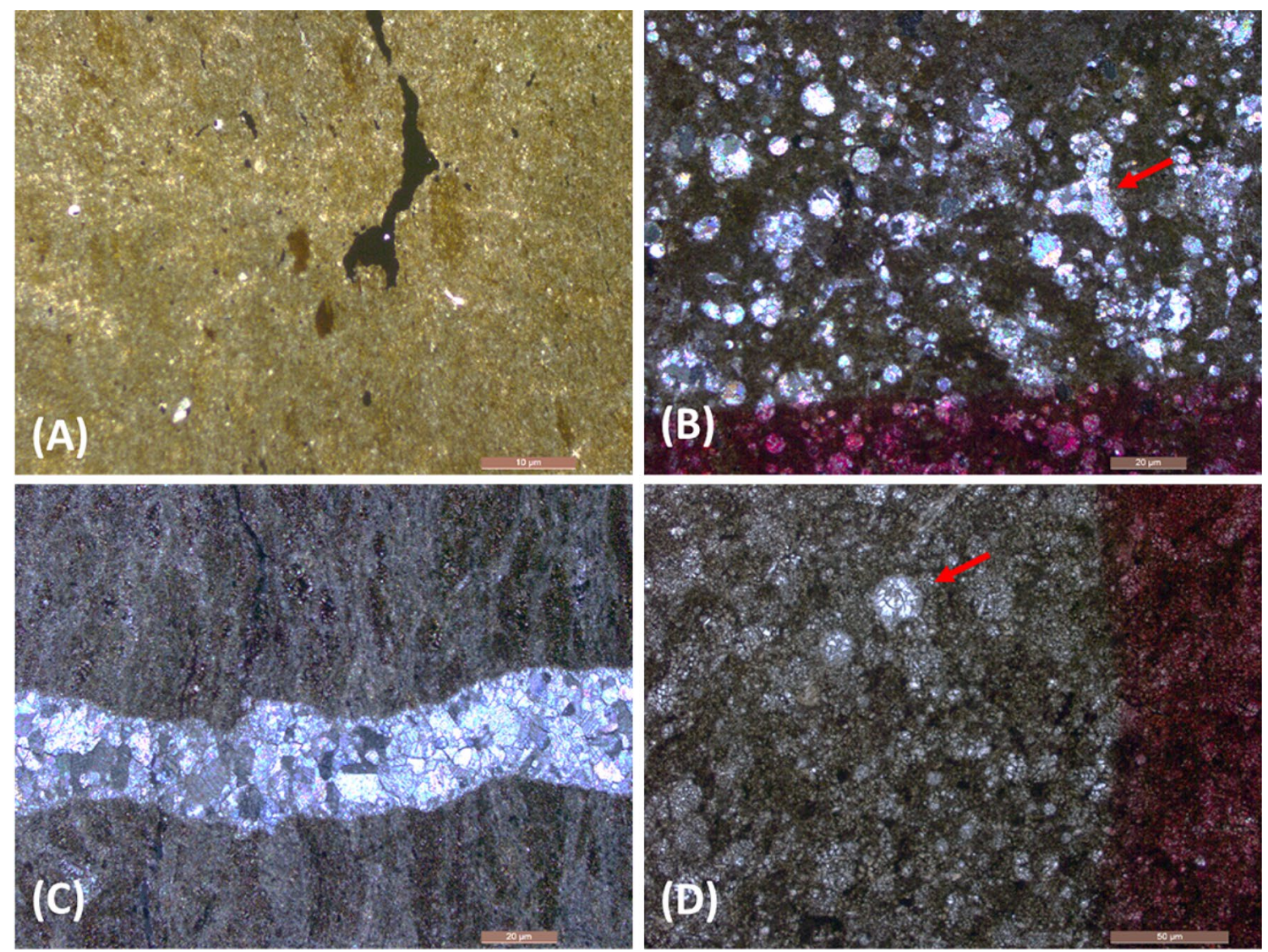

Fig. 7 a Micritic groundmass containing high percentage of organic matter, and neomorphosed to microsparite. Vuggy porosity is t filled with organic matter, Br-64, X.N., b Granular Cement (arrow) in a mold of radiolaria, creating moldic porosity within the sponge Spicules, Br-43, X.N., c Drusy cement (arrow), within articulated ostra-

units, shale and limestone. The argillaceous limestone and limestone of this formation are highly fractured (Macro and Micro), both of them are observed in the field and under microscope and usually filled with calcite (Fig. 8e, f). Tucker (2001) suggested that porosity reduction is complex and can involve compaction, cementation or combinations from two types. In this study, the main porosity type is primarily fracture and to a lesser degree, moldic and/or vuggy types. These types are usually occluded by organic matter and sparry calcite (Fig. 7a, d).

The more common secondary porosity is a substantial result of dissolution, porosity modification by dolomitization, fracturing, and brecciation (Lucia 2007; Ahr 2008). Secondary porosity created by dissolution can essentially enhance reservoir properties as it occurs at any point in burial history (Flugel 2010). Secondary porosity in Chia Gara is significantly reduced by diagenetic processes such as cementation (Fig. 8a, b). Both porosity and permeability are incubator for reservoir quality (Tucker 2001; Ahr 2008). Though porosity in Chia Gara is partly sufficient for

cods, Bk-1, P.P. d Blocky cement filling a vein also fractured porosity, Bk-4, X.N. e Neomorphosed skeletal grain (arrow) (possibly a radiolaria) with micritic matrix, primary depositional texture is intensively altered, Bk-30, P.P

reservoir quality, its permeability is small and somewhat not relevant for reservoir qualifications. This situation is aided by fractures cementation and disconnected vugs as well as moldic connectivity to be ineffective. Accordingly, the studied sections of Chia Gara are generally of poor reservoir quality, although in some compartments, porosity is high but associated with notably low permeability. On the other hand, stylolites "non-sutured type" was observed in several thin sections (Fig. 8d). These rock units of these stylolites are enriched by organic matter and have higher porosity; they may create good migration channels of oil and gas from source rocks. Therefore, it is believed that there is strong heterogeneity in distribution of organic matter in carbonate rocks. The organic matter content is higher in stylolite, carbonate varve or marl but lowest in matrix (purer carbonate rock around stylolite) (Flugel 2010). Accordingly, hydrocarbon generation and expulsion would be lower in units lacking stylolites than those including them.

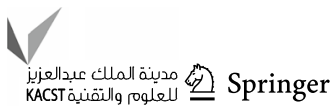




४Fig. 8 a Three generations of fractures $(1,2,3)$ all filled with postdating sparry calcite with, common radiolaria and calcispheres in micritic matrix, Br-46, P.P., b Broken sponge spicules (a), and deformed mold of radiolaria (b) due to compaction, cross-cutting fractures represented two stages of fracturing, a young one (c) cutting an old one (d) in micritic matrix. This may indicate strong tectonic and/or deep burial effect. Br-57, P.P. c Orientation of radiolaria, radiolaria are deformed and lost their spherical shape due to intensive compaction (a), the organic matter flatted between oriented grains (b)., Br-50, X.N., d Phosphatized valve of pelecypod, in microsparite matrix, also Non-Sutured Seam Stylolite, anastomosing type (parallel set) in strongly neomorphosed limestone (arrow). Br-2, P.P., e Highly fractured limestone with micritic matrix. Br-59, P.P., f Macrofracture in limestone of Chia Gara Formation in lower part of Barsarin section. g Dolomitization of Chia Gara Formation, Aj-12, 3392, P.P., h Ball and Pillow structure in lower part of Chia Gara Formation in Banik section, this is might have formed by slumping and sliding in a slope during deposition of the Chia Gara Formation (a syndepositional structure), pen is used as a scale

\section{Source Rock Evaluation of the Chia Gara Formation}

\section{Source rock evaluation in Well Aj-12}

Rock-Eval data for samples in well $\mathrm{Aj}-12$ show that TOC\% values range from 0.39 to $1.65 \%$ with an average of $0.98 \%$ (Table 5). This range can be described as fair in lower part, and good in middle part, while in upper part is again fair (Fig. 11). S2 ranges from 0.35 to $5.65 \mathrm{mgHC} / \mathrm{g}$ rock, indicating a potentiality range from poor to good (Table 5 and Fig. 11). The middle part has shown good potentiality. Moreover, the Hydrogen Index (HI) of the analyzed samples ranges from 94-342 mgHC/g TOC, which suggests mixed oil-gas-prone and terrestrial gas-prone (Fig. 11). Using the $\mathrm{HI}$ vs. OI diagram, the OM in the samples can be classified as mixed type-II and type-III kerogen (Fig. 12a). The plot of TOC $\%$ vs. S2 points out kerogen type of II/III and III, which indicates mixed oil-gas prone and gas-prone (Fig. 12b). The ratio $\mathrm{S} 1 / \mathrm{TOC}$ ranges from 38 to 179 . As shown in geochemical $\log$ in Fig. 11, there are three categories of oil content: low maturity source rock, mature stained source rock, and oil-gas production or contamination (Fig. 11). To determine maturity of the Chia Gara Formation in Aj-12, the HI and OI vs. $T_{\max }$ (Fig. 13) shows that the analyzed samples lie in field of immature which suggested stained or contaminated. The kerogen type is interpreted as types II/III and III kerogens, except for two samples that belong to type-IV kerogen (Fig. 12a). The Production Index (PI) of the analyzed samples indicates maturity of OM of this section (Table 5).

A plot of S1 vs. TOC\% can be used to discriminate between indigenous and non-indigenous hydrocarbons (Rabbani and Kamali 2005). In consequence, migrated or contaminating hydrocarbons can be distinguished from indigenous hydrocarbons (Fig. 14). Rock samples of Chia Gara Formation in all studied sections have relatively high TOC\% and low $\mathrm{S} 1$ values indicating the presence of indigenous oil, thus in situ oil generation except in one sample that is located in non-indigenous hydrocarbons field (Fig. 14). The anomalous position of this sample is reasoned by: first the sample is very close to the line of discrimination. Second, as it is clear, the indigenous oil always has low S1 and high TOC\% (in situ oil), but as this sample has high S1 and relatively low TOC\%, then the oil may be from the other areas (i.e. non-indigenous oil). Third, it may be the results of inaccurate sampling.

Depending on the cross-plot of TOC\% vs. Generation Potential (S1 +S2) (Fig. 15), a general evaluation of Chia Gara behavior as source rock in the studied sections has been interpreted. This plot displays that Aj-12 and Barsarin sections appeared to be poor-fair (mainly fair), while Banik section would express fair-very good source rock.

\section{Source Rock Evaluation in Banik Area}

The organic carbon content of the samples (Table 5) ranges from $1.74 \%$ to $5.03 \%$, with average of $3.40 \%$. These TOC $\%$ values are above the generally accepted minimum value of $0.5 \%$ TOC for argillaceous hydrocarbon source rocks (Tissot and Welte 1984). Middle part of formation in this section contain higher TOC\% and lower part has lower percentage of TOC. According to parameters classification of Peters and Cassa (1994), the rocks of the Chia Gara in this area would be considered as very good source rock.

On the graph of HI versus OI (Fig. 12a), two samples (Bk.11 and 21) are plotted in the field of type-II kerogen; this type corresponds to common marine organic matter which is mainly derived from phytoplanktonic organisms. Accordingly, it is considered as a typical oil source kerogen (Nunez-Betelu and Baceta 1994). Sample Bk.32 falls in the area of type-III kerogen which corresponds to common terrestrial organic matter that is derived from higher land plants. This type of organic matter is rich in lignin and cellulose and, unless the plant remains are enriched in cuticles, sporomorphs, or resinite, this type of kerogen only yields gas. However, if this type of kerogen is enriched with waxy materials (i.e., plant cuticles) from higher plants, waxy oil can be produced from terrestrial organic matter (NunezBetelu and Baceta 1994).

Despite its terrestrial origin, the type-III kerogen may dominate in marine shale (Hunt 1996; Tissot and Welte 1984). Whereas sample Bk.5 is located in the field of typeIV kerogen which consists mainly of black, opaque debris derived from lignified precursors, such as woody material highly altered by oxidation. This type of kerogen mainly corresponds to inertinite and is often called "dead-carbon". It has no effective potential for oil and very little, if any, for gas (Brooks and Fleet 1987). The very low HI and the high OI may suggest that this is highly reworked and oxidized terrestrial organic matter (Hunt 1996).

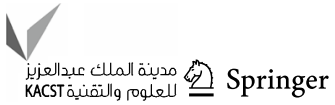



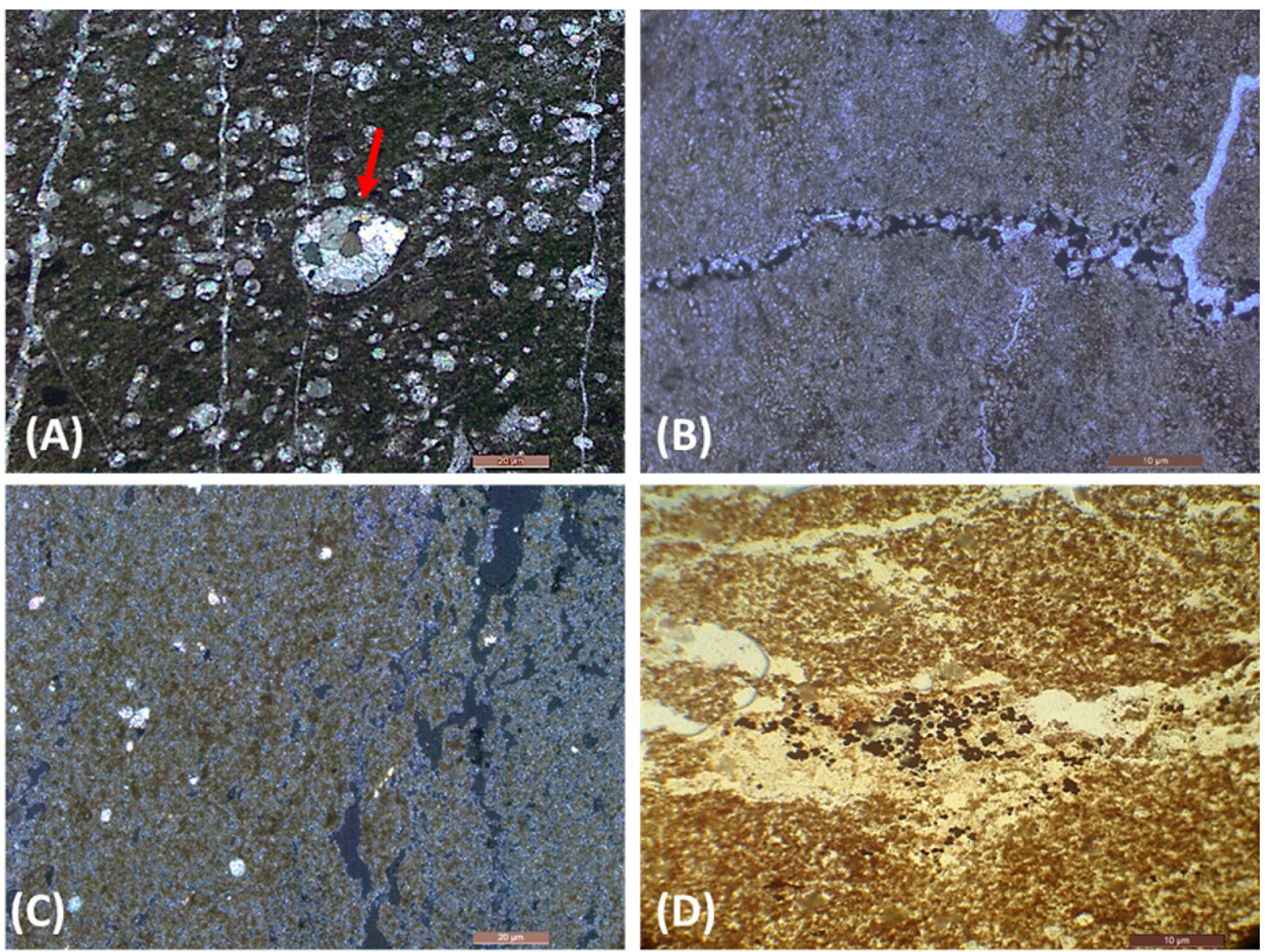

Fig. 9 a Moldic Porosity (arrow), a type of secondary porosity filled with sparry calcite (granular cement). Br-47, X.N. b Fractured Porosity, filled with pyrite and/or organic matter in micritic matrix. Bk-4,

Types II/III, III, and type IV of kerogen are also indicated by plot of TOC\% versus S2 (Fig. 12b) in which mixed type II/III is oil-gas prone, type-III gas prone and type-IV inert. The values of Hydrogen Index (HI), which ranges from 62 to 290 with an average 197, and S2/S3 values show type-II/ III-III kerogen. The $\mathrm{T}_{\max }$ values were generally higher than $435{ }^{\circ} \mathrm{C}$ (Table 5, Fig. 13a) indicating that the formation is

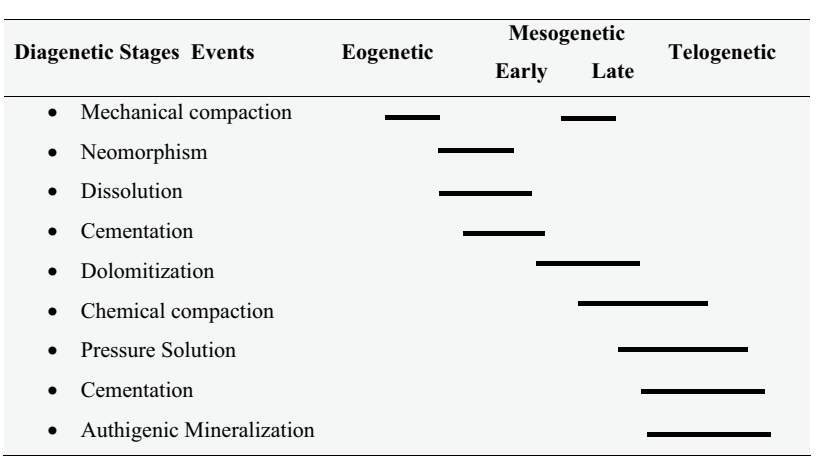

Fig. 10 General paragenetic sequence of Chia Gara Formation in studied sections
X.N., c Solution enlarged fracture with Radiolarian mold, Br-38, X.N., d Framboidal pyrite in micritic matrix, possibly indicating anoxic (Reducing) environment of deposition, Br-39, P.P

mature and within oil window. According to discrimination of Tissot and Welte (1984), Generation Potential (GP) of the Chia Gara Formation ranges from 1.17 to 15.18 with an average of 8.74 that shows very good source rock. By plotting $T_{\max }$ vs. PI, the Chia Gara samples would be located in oil window with intensive generation expulsion (Fig. 13b). The PI of analyzed samples shows immaturity stage in this section of the Chia Gara Formation.

\section{Source Rock Evaluation in Barsarin Area}

The samples of Barsarin area display TOC\% values ranging from 1.90 to $2.01 \mathrm{wt} . \%$ with mean value of $1.70 \mathrm{wt} . \%$ (Table 5) that represent a good source rock. The higher TOC $\%$ was observed in the middle part, while the upper part has the lower TOC\%. Organic matter of Chia Gara in this section yields $\mathrm{HI}$ values of $15-105 \mathrm{mg} \mathrm{HC} / \mathrm{g}$ TOC, and OI values of $20-49 \mathrm{mg} \mathrm{CO} / \mathrm{g}$ TOC (Fig. 12a) which is typical for gas-prone. Additionally, the plot of TOC\% vs. S2, shows type-III-IV kerogens that is gas-prone and inert (Fig. 12b). The plot of samples on the diagrams of the HI vs. $T_{\max }$, and of Production Index (PI) vs. $T_{\max }$ suggest that Chia Gara`s 
Table 3 Classification of diagenesis and its presence in the Chia Gara Formation (after Engelhardt 1977)

\begin{tabular}{|c|c|c|c|}
\hline \multicolumn{2}{|l|}{ Diagenesis } & \multirow{2}{*}{$\begin{array}{l}\text { Presence in Chia Gara } \\
\text { formation }\end{array}$} & \multirow[t]{2}{*}{ Figure (s) } \\
\hline Divisions & Processes & & \\
\hline Mechanical diagenesis & Compaction & $\mathrm{p}$ & Figure $8 \mathrm{a}, \mathrm{b}, \mathrm{c}$ \\
\hline \multicolumn{4}{|l|}{ Chemical diagenesis } \\
\hline $\begin{array}{l}\text { Isochemical: No chemical or } \\
\text { mineral change }\end{array}$ & $\begin{array}{l}\text { Neomorphism } \\
\text { Solution } \\
\text { Cementation }\end{array}$ & $\begin{array}{l}\mathrm{C} \\
\mathrm{P} \\
\mathrm{P}\end{array}$ & $\begin{array}{l}\text { Figure } 7 \mathrm{e} \\
\text { Figure } 8 \mathrm{~d} \\
\text { Figures } 7 \mathrm{~b}, \mathrm{~d} 6 \mathrm{~b}\end{array}$ \\
\hline $\begin{array}{l}\text { Allochemical: with chemi- } \\
\text { cal and mineral change }\end{array}$ & $\begin{array}{l}\text { Dolomitization } \\
\text { Dedolomotization } \\
\text { Silicification } \\
\text { Phosphatization }\end{array}$ & $\begin{array}{l}\mathrm{R} \\
\mathrm{NOb} \\
\mathrm{NOb} \\
\mathrm{R}\end{array}$ & $\begin{array}{l}\text { Figure } 8 \mathrm{~g} \\
\text { Figure } 8 \mathrm{~d}\end{array}$ \\
\hline
\end{tabular}

$R$ rare, $P$ present, $C$ common, $N O b$ not observed organic matter is at the end of mature to postmature stage that produce Condensate-Wet Gas Zone to Dry Gas Window (Figs. 12, 13). According to Peters and Cassa (1994), the results of analysis of $\mathrm{HI}$ and S2/S3 show that the kerogen type in this area belongs to type-III and type-IV kerogens, and that main expelled production at peak maturity is gas.

\section{Vitrinite reflectance $\left(\% \mathrm{R}_{\mathrm{o}}\right)$ the Chia Gara Formation}

Nine rock samples from three locations were analyzed for vitrinite reflectance $\left(\% \mathrm{R}_{\mathrm{o}}\right)$. The $\mathrm{R}_{\mathrm{o}}$ values vary from $0.59 \%$ to $1.04 \%$ (Table 6). Thermal maturity and visual kerogen study indicate that the samples of Banik and well $\mathrm{Aj}-12$ are in the early stage of thermal maturity. However, the Barsarin samples are in the late stage of thermal maturity (Table 6). Accordingly, the source rocks in Banik and well Aj-12 are currently producing liquid hydrocarbon; whereas in Barsarin area the source rock had produced liquid hydrocarbon in the past, and now may produce gas (Table 6).

\section{Conclusions}

Petrographic study of Chia Gara Formation had shown homogenous petrographic contents in the limestones in all studied sections. Matrix is mainly composed of micrite,

Table 4 Types of porosity in the Chia Gara Formation

\begin{tabular}{ll}
\hline Type of porosity & $\begin{array}{l}\text { Present in the } \\
\text { Chia Gara For- } \\
\text { mation }\end{array}$ \\
\hline Moldic porosity & Figure 9a \\
Fracture porosity & Figure 9b \\
Solution enlarged fracture & Figure $9 \mathrm{c}$ \\
Microfractures connecting moldic pores & Figures $6 \mathrm{c}, 8 \mathrm{a}$ \\
\hline
\end{tabular}

various diagenetic processes had influenced limestones of Chia Gara Formation, which are, in ascending order of significance: neomorphism, dissolution, calcification, cementation, and compaction. The effect of diagenesis was not consistent among studied sections, being more intensive in Banik and Barsarin sections compared to $\mathrm{Aj}-12$ well. Those might be resulted from deeper burial and proximity to effective tectonic zones. The rocks of Chia Gara Formation can possess high porosity, mainly microporosity that included fracture, vuggy and moldic. Porosity was later destroyed by digenetic processes (filled with sparry calcite and organic matter). Permeability seems to be low, which explains why this formation is not considered as good reservoir rock.

The organic matter richness (TOC) and remaining hydrocarbon potential (S2) of Chia Gara Formation in the studied sections indicate fair (Aj-12), good (Barsarin) and very good (Banik) for source rock potential. TypeIII kerogen and mixed type-II/type-III kerogen have been concluded for the Banik section and well $\mathrm{Aj}-12$ that are oil-gas-prone. The samples of Barsarin section, on the other hand, suggest type-III/type-IV kerogen which is probably gas-prone.

Thermal maturity parameters show that well Aj-12 is in late stage of thermal immaturity (or early stage of maturity), Banik is in mature stage, and Barsarin is in late stage of thermal maturity. In Banik section and well Aj-12, source rocks are currently producing liquid hydrocarbon, while in Barsarin, source rock had generated liquid hydrocarbon in the past and now may generate gas. The source of generated hydrocarbons in Chia Gara rocks is probably indigenous in all sections, except for one sample of well Aj-12 that contains non-indigenous hydrocarbons (oil). 


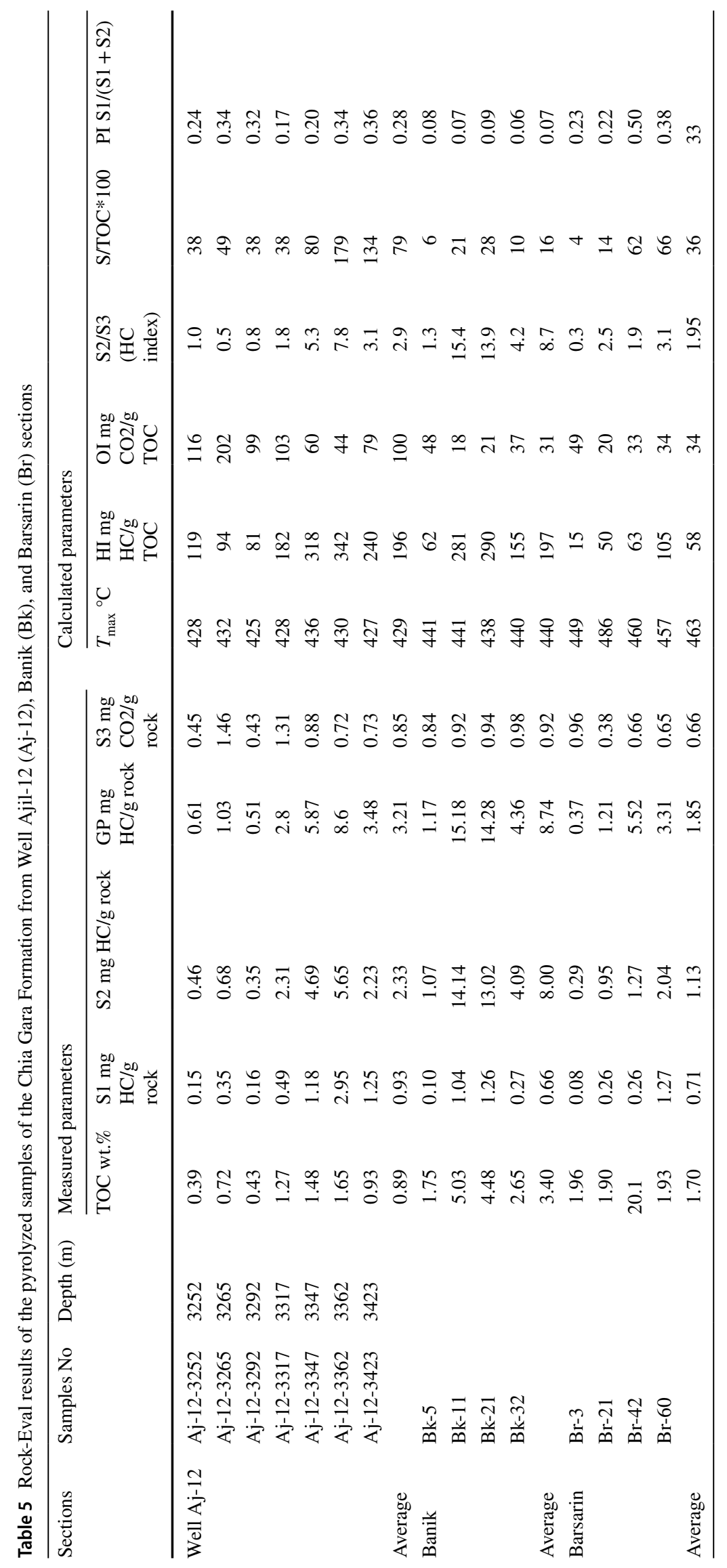




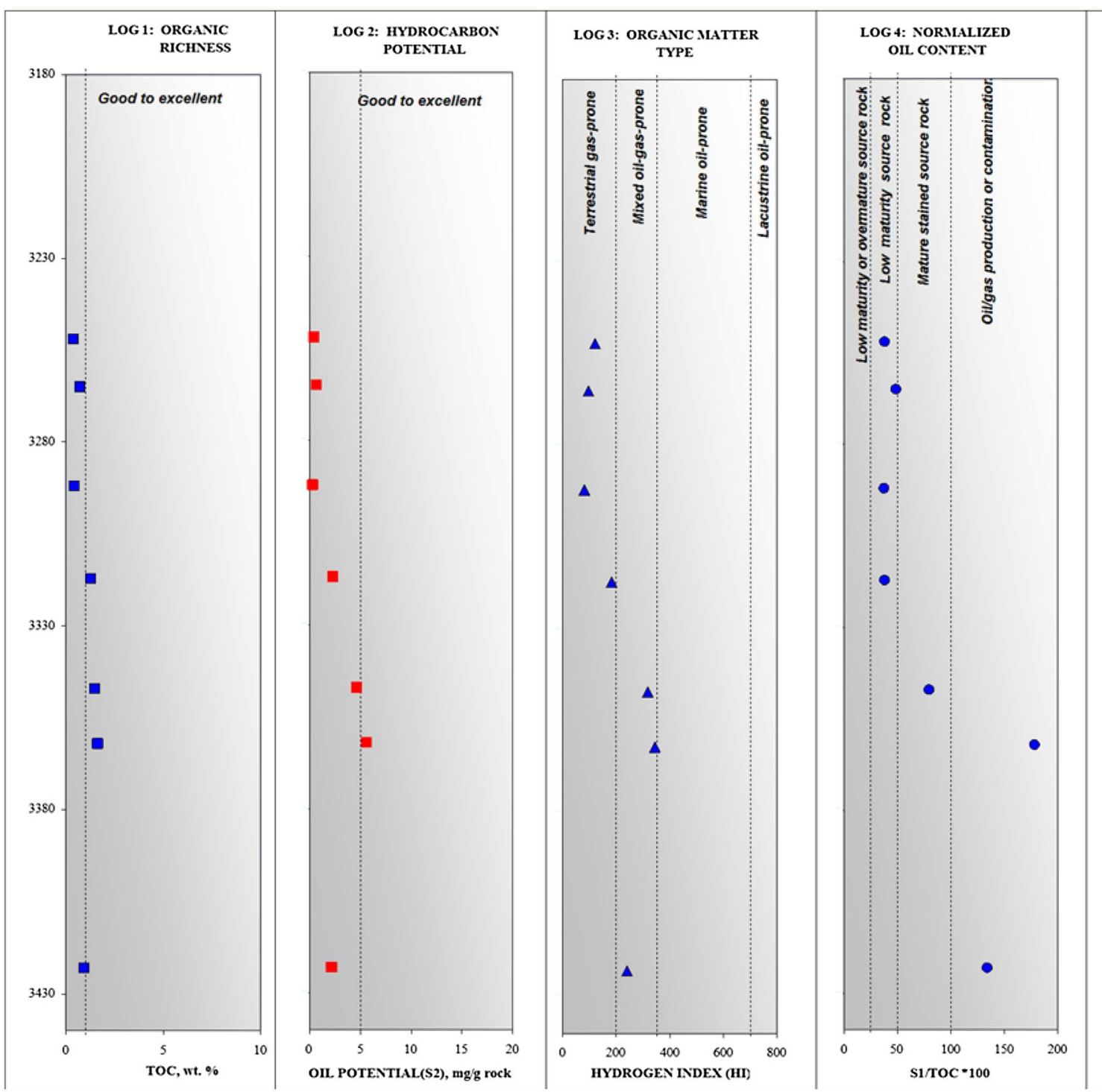

Fig. 11 Geochemical log for Chia Gara Formation in well Aj-12. The depth 3300-3380 m is relatively organic richness and shows a good hydrocarbon potential 


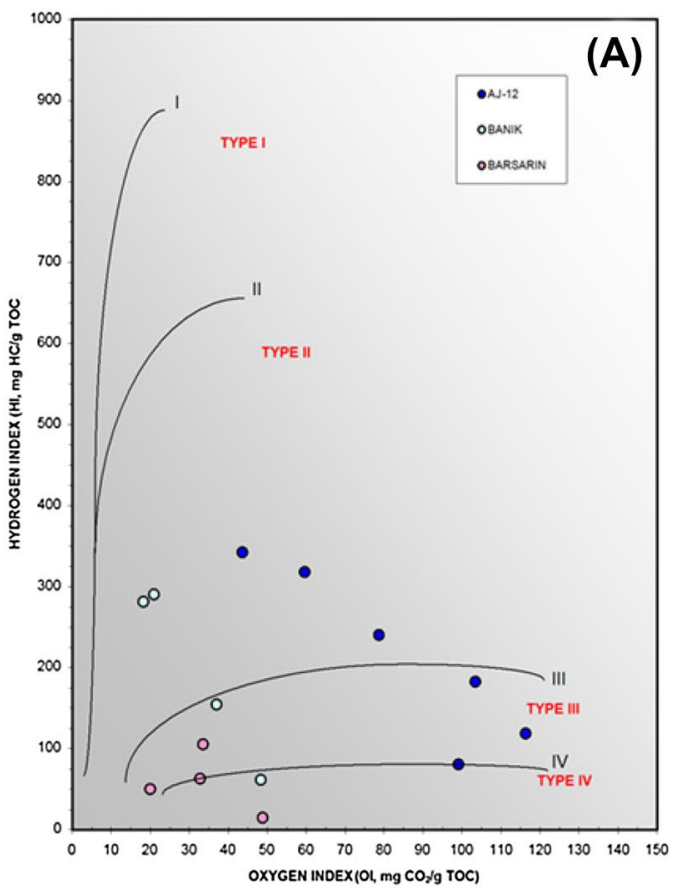

Fig. 12 a Cross plot of HI vs. OI of Chia Gara Formation, b Plot of Total Organic Carbon (TOC \%) vs. S2 for source rock of the Chia Gara Formation. Samples from well Aj-12 and Banik sections are

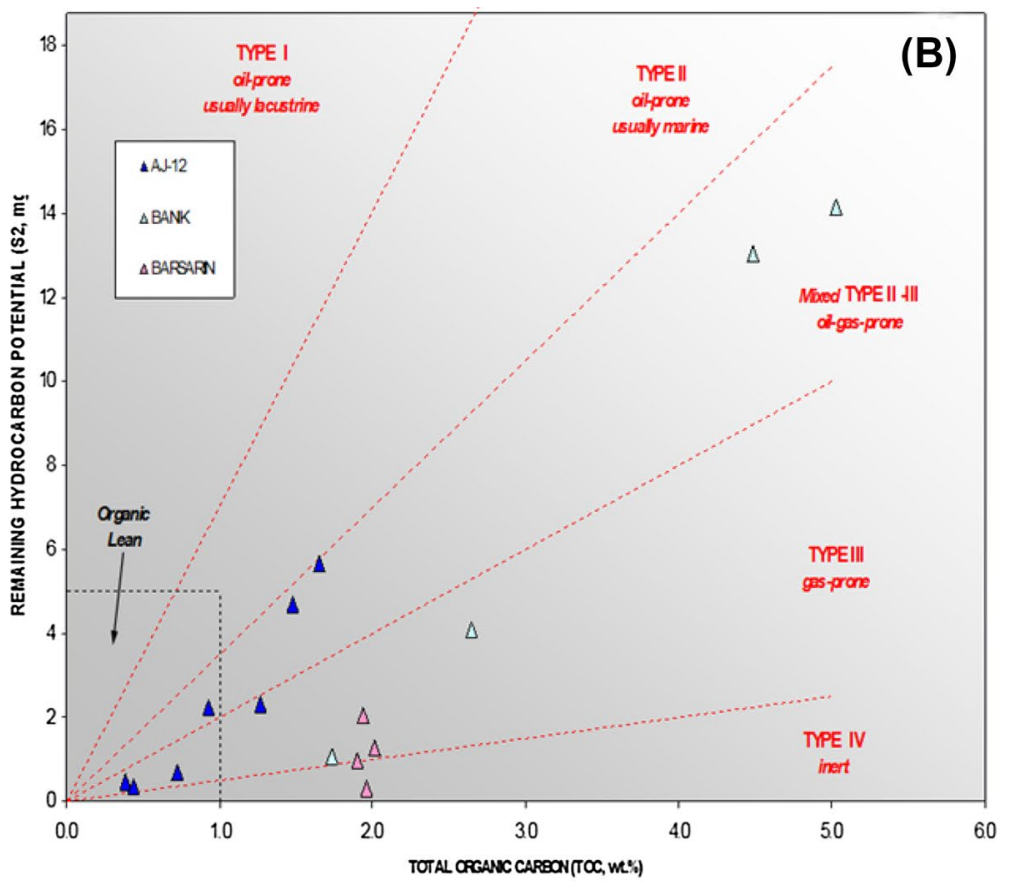

considered as type mixed II-III kerogens, whereas samples of Barsarin belong to type-IV kerogen. This difference in type kerogen can be due to thermal evolution of organic matter (see Fig. 13)

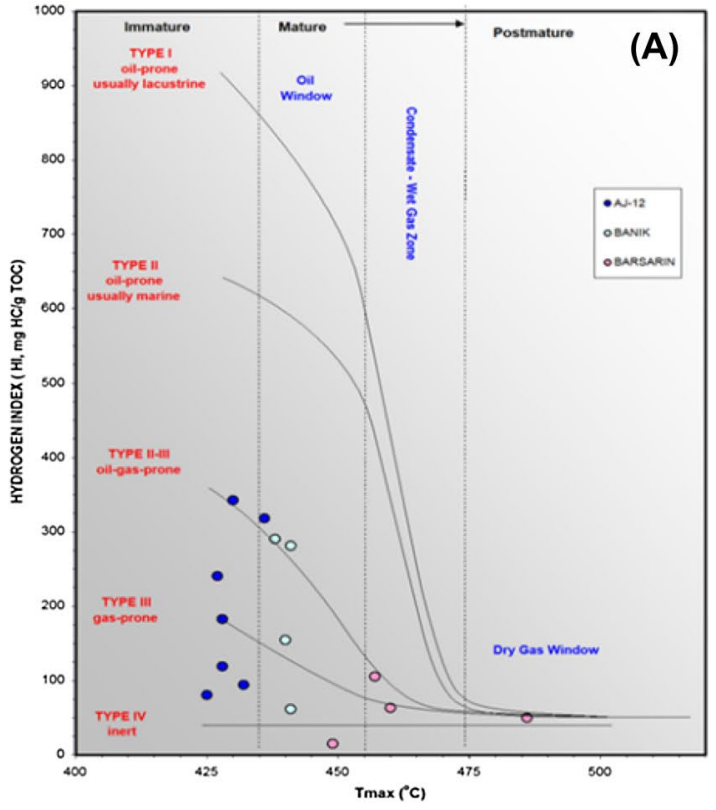

Fig. 13 a Plot of Hydrogen Index (HI) vs. $T_{\max }$ of the samples of the Chia Gara Formation, $\mathbf{b} T_{\max }$ vs. Production Index (PI) diagram of the Chia Gara Formation. Thermal maturity parameters show that sam-

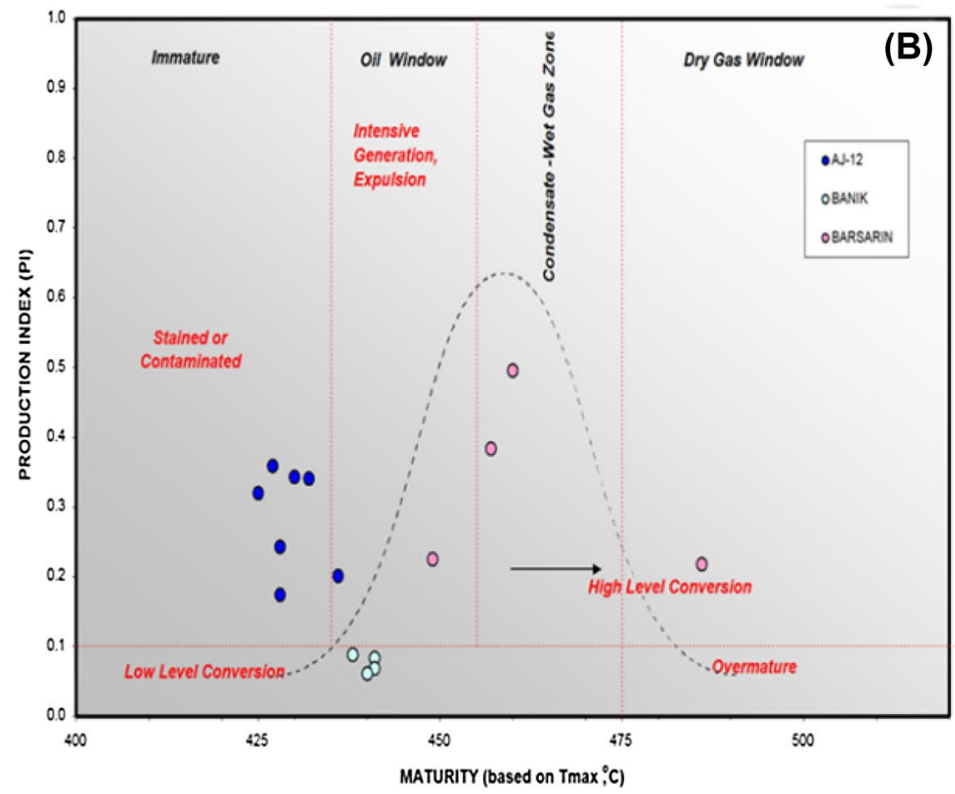

ples from well Aj-12 are in late stage of immaturity, samples of Banik area are in the mature stage; however, samples from Barsarin section are in the late stage of thermal maturity to postmature zone 


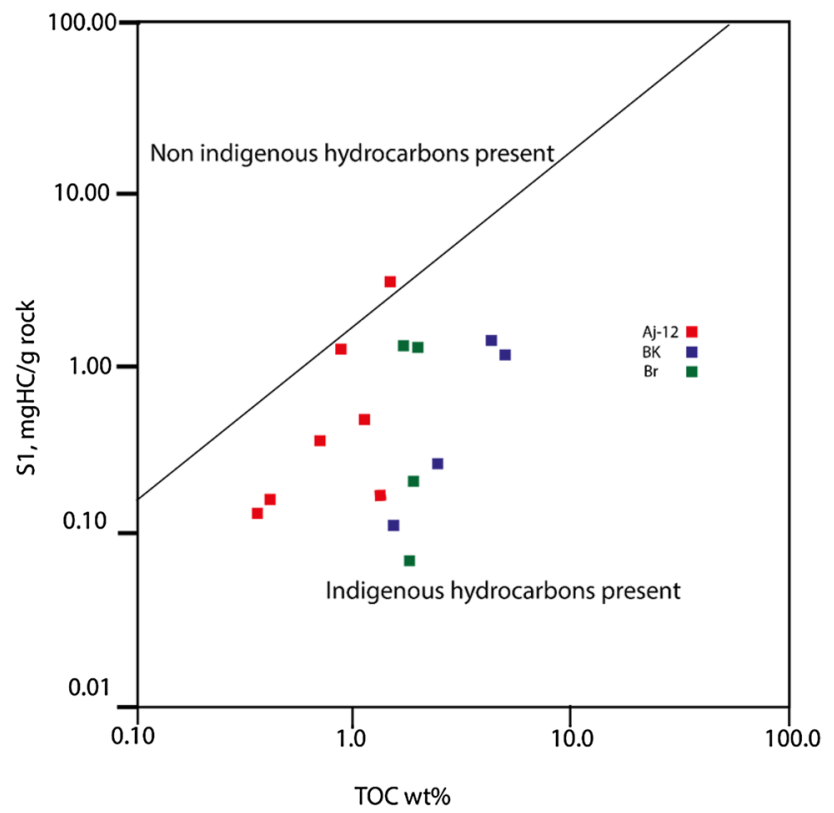

Fig. 14 Plot of S1 vs. TOC\% of the rocks of Chia Gara Formation. All samples seem to be indigenous hydrocarbon, except one sample from well Aj-12. This sample can be considered as contaminated or migrated sample

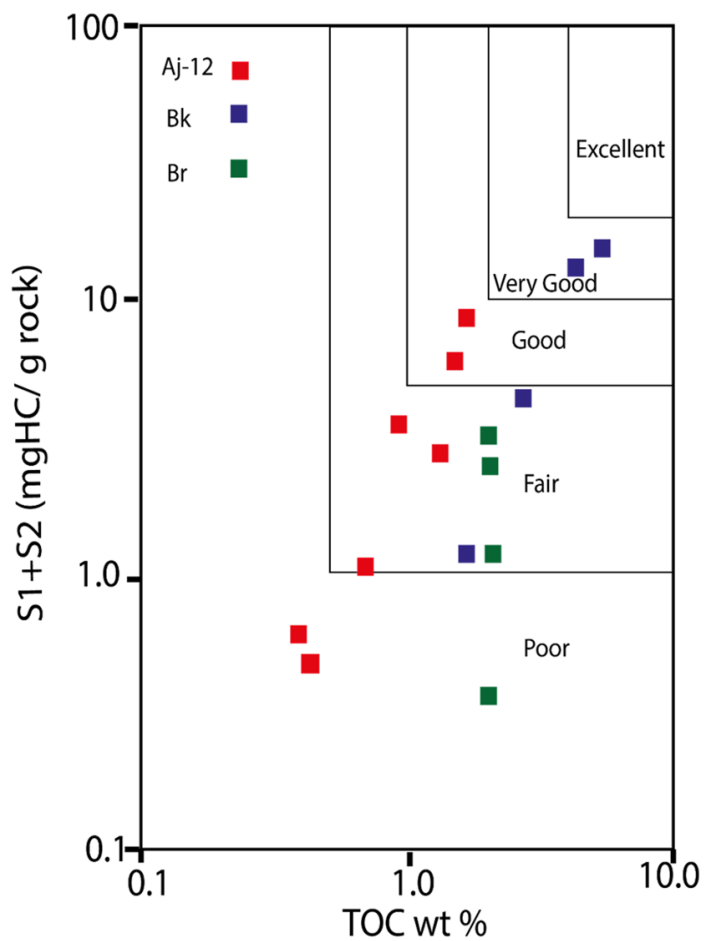

Fig. 15 TOC\% vs. Generation Potential GP $(\mathrm{S} 1+\mathrm{S} 2)$ for the Chia Gara Formation. The Generation Potential of the studied samples indicates poor to very good potentiality
Table 6 The values of vitrinite reflectance of the Chia Gara Formation

\begin{tabular}{lllll}
\hline Section & $\mathrm{R}_{\mathrm{o}}$ Value & & & Average \\
\hline Banik & 0.66 & 0.64 & 0.63 & 0.64 \\
Barsarin & 1.03 & 1.03 & 1.04 & 1.03 \\
Aj-12 & 0.61 & 0.59 & 0.62 & 0.61 \\
\hline
\end{tabular}

Acknowledgements Authors wish to thank Gulf Keystone Petroleum Company for financial support. They are also grateful to the geologist staff of NOC in Kirkuk for providing rock samples and for their kind cooperation. Appreciation is extended to Mr. Ababakr and Mr. Yahya in Directorate of Ground Water-Duhok for their help during field work.

Open Access This article is distributed under the terms of the Creative Commons Attribution 4.0 International License (http://creativeco mmons.org/licenses/by/4.0/), which permits unrestricted use, distribution, and reproduction in any medium, provided you give appropriate credit to the original author(s) and the source, provide a link to the Creative Commons license, and indicate if changes were made.

\section{References}

Ahr WM (2008) Geology of carbonate reservoir: the identification, description, and characterization of hydrocarbon reservoirs in carbonate rocks. Wiley, Hoboken, p 277

Al-Ameri TK, Al-Obaidi RY (2004) Palynomorphs and alkane peaks of Campanian Khasib Formation, oil used to assess oil-source correlation and suggestion for other traps along the migration path, East Baghdad oil field, Iraq. In: 6th International conference on geochemistry, Alexandria University, Egypt, pp. 243-255

Al-Badry AMS (2012) Stratigraphy and geochemistry of Jurassic formations in selected sections-North Iraq; PhD thesis (Unpublished), University of Baghdad

Al-Jaafary AS, Hadi A (2015) Hydrocarbon potential, thermal maturation of the Jurassic sequences, and the genetic implication for the oil seeps in North Thrust Zone, North Iraq. Arab J Geosci 8:8089-8105. https://doi.org/10.1007/s12517-015-1781-z

Al-Sharhan AS, Nairn AEM (1997) Sedimentary basin and petroleum geology of the Middle East. Elsevier Science

Aqrawi AAM, Badics B (2015) Geochemical characterization, volumetric assessment and shale-oil/gas potential of the Middle Jurassic-Lower Cretaceous source rocks of NE Arabian Plate. GeoArabia 20(3):99-140

Aqrawi AAM, Goff JC, Horbury AD, Sadooni FN (2010) The petroleum geology of Iraq: Beaconsfield. Scientific Press Ltd., United Kingdom, p 424

Bellen RC, van, Dunnington HV, Wetzel R, Morton DM (1959) Lexique Stratigraphique International. V. III, Asie, Fasc., 10a Iraq. Paris

Brooks J, Fleet AJ (1987) Marine petroleum source rocks. Geological Society Spec. Publ. 26, Oxford, Blackwell Publication

Buday T (1980) The regional geology of Iraq, vol 1, stratigraphy and paleogeography. Dar Al-Kutub Publication, University of Mosul, Iraq

Choquette PW, Pray LC (1970) Geologic nomenclature and classification of porosity in sedimentary carbonates. AAPG. Bull $54: 207-250$ 
Curiale JA (1994) Correlation of oils and source rocks-a conceptual and Historical Prospective. In: Magoon LB, Dow WG (eds) The Petroleum system-from source to trap. AAPG, Memoir 60, pp 251-260

Demaison G, Moore GT (1980) Anoxic environment and oil source bed genesis. AAPG 64:1179-1209

Dunnington HV (1958) Generation, migration, accumulation, and dissipation of oil in Northern Iraq. In: Weeks LG (ed) Habitat of oil, a symposium, AAPG. Bull, pp 1194-1251

Edilbi ANF (2016) The role of the Baluti Formation within Triassic Petroleum Systems in Kurdistan; Akre-Bijeel Block, Gara and Ora anticlines. An organic geochemical and basin modelling approach. PhD Thesis, University of Aberdeen

Edilbi ANF, Sherwani GH (2018) Sedimentology and Petroleum Potential of Chia Gara Formation (Late Jurassic-Early Cretaceous) in three different tectonic zones in Northern Iraq and Kurdistan Region, 13th Middle East Geosciences conference and Exhibition (GEO2018), March 5-8, 2018-Manama, Bahrain

Engelhardt WV (1977) The origin of sediments and sedimentary rock. Eschwizerbartsche, Verlagsbuchhanlung (Nagele U. Obermiller) Stuttgart. Wiley, New York

English JM, Lunn GA, Ferreira L, Yaku G (2015) Geologic evolution of the Iraqi Zagros, and its influence on the distribution of hydrocarbons in the Kurdistan Region. AAPG Bull 99(2):231-272

Flugel E (2010) Microfacies of carbonate rocks-analysis, interpretation and application, 2nd edn. Springer, Berlin, pp 1-984

Hunt JM (1996) Petroleum geochemistry and geology, $2^{\text {nd }} e d n$, Cambridge

Jassim SZ, Buday T (2006) Latest Eocene-Recent Megasequence AP11. In: S Z Jassim and J Goff (eds) Regional geology of Iraq. Dolin, Prague and Moravian Museum, Brno, Czech Republic, pp $71-183$

Larsen G, Chilingar GV (1979) Introduction- diagenesis of sediments and rocks. In Larsen G, Chilingar GV (eds) Diagenesis sediments and sedimentary rocks. Development in sedimentology 25 A., Elsevier, pp. 1-29

Li YH, Schoonmaker JE (2004) Chemical composition and mineralogy of marine sediments. In: Holland HD, Turekian KK (eds) Treatise on geochemistry, Elsevier-Pergamon, pp 1-35

Lucia FJ (2007) Carbonate Reservoir Characterization, 2nd edn. Springer, Berlin, p 336

Mohialdeen IMJ, Hakimi MH, Al-Beyati FM (2013) Biomarker characteristics of certain crude oils and the oil-source rock correlation for the Kurdistan oilfields. Arab J Geosci, Northern Iraq. https:// doi.org/10.1007/s12517-013-1228-3
Mohyaldin IMJ (2008) Source rock appraisal and oil/source correlation for the Chia Gara Formation, Kurdistan-North Iraq. PhD thesis (unpub.), University of Sulaimani

Mohyaldin IMJ, Al-Beyati FM (2008) Sedimentology and hydrocarbon generation potential of Middle Tithonian-Berriasian Chia Gara Formation, Well K-109, Kirkuk Oil Field. Kirkuk Univ J 2(1):27-43

Murris RJ (1980) Middle east-stratigraphic evolution and oil habitat. AAPG Bull 64(5):597-618

North Oil Company (NOC) (1985) Final report of well Aj-12, Kirkuk, NE Iraq

Numan NMS (1997) A plate tectonic scenario for the Phanerozoic succession in Iraq. Iraqi Geol J 30(2):85-110

Numan NMS (2000) Major cretaceous tectonic events in Iraq. Rafidain J Sci 11(3):32-54

Nunez-Betelu L, Baceta JI (1994) Basic and application on Rock-Eval/ TOC Pyrolysis: and example from the upper Paleocene/Lowermost Eocene in the Basque Basin, Western Pyrenees. Munibe (Ciencias Naturales) 46:43-62

Odisho KY, Othman RS (1992) Preliminary geochemical evaluation of hydrocarbon source rocks in northern part of Iraq. Iraqi Geol J 25:136-153

Peters KE, Cassa MR (1994) Applied source rock geochemistry. In: Magoon LB, Bow WG (eds) The petroleum system- from source to trap. AAPG Memoir 60, pp 93-120

Rabbani AR, Kamali MR (2005) Source rock evaluation and petroleum geochemistry, offshore SW Iran. J Pet Geol 28(4):413-428

Sharland PR, Archer R, Casey DM, Davies RB, Hall SH, Howard AP, Horbury AD, Simmons MD (2001) Arabian Plate sequence stratigraphy, GeoArabia, Special Publication 2. Gulf PetroLink, Bahrain, p 372

Tissot BP, Welte DH (1984) Petroleum Formation and occurrence: a new approach to oil and gas exploration, 2nd edn. Springer, Berlin, p 699

Tucker ME (2001) Sedimentary petrology: an introduction to the origin of sedimentary rocks, 3rd ed. Blackwell Publishing Co

Wetzel R (1950) Stratigraphy survey in North Iraq. MPC report, NIMCO Library, No. 139, Baghdad

Publisher's Note Springer Nature remains neutral with regard to jurisdictional claims in published maps and institutional affiliations. 